\title{
Insulin-Mimetic Action of Vanadium Compounds on Osteoblast-like Cells in Culture
}

\author{
S. B. Etcheverry, ${ }^{*, \dagger}{ }^{+1}$ D. C. Crans, $\ddagger^{1}$ A. D. Keramidas, $\ddagger$ and A. M. Cortizo ${ }^{*, 2}$ \\ * Cátedra de Bioquímica Patológica, †CEQUINOR, Facultad de Ciencias Exactas, Universidad Nacional \\ de La Plata, $47 y 115$ (1900) La Plata, Argentina, and $\ddagger$ Department of Chemistry, Colorado State \\ University, Fort Collins, Colorado 80521
}

Received August 19, 1996, and in revised form October 21, 1996

Vanadium compounds mimic insulin actions in different cell types. The present study concerns the insulin-like effects of three vanadium(V) derivatives and one vanadium(IV) complex on osteoblast-like (UMR106 and MC3T3E1) cells in culture. The vanadium oxalate and vanadium citrate complexes hydrolyzed completely under the culture conditions, whereas more than $40 \%$ of the vanadium tartrate and nitrilotriacetate complexes remained. Vanadate, as well as vanadium oxalate, citrate, and tartrate complexes enhanced cell proliferation (as measured by the crystal violet assay), glucose consumption, and protein content in UMR106 and MC3T3E1 osteoblast-like cells. The vanadium nitrilotriacetate complex (the only peroxo complex tested) stimulated cell proliferation in UMR106 but not in MC3T3E1 cells. This derivative strongly transformed the morphology of the MC3T3E1 cells. All vanadium(V) compounds inhibited cell differentiation (alkaline phosphatase activity) in UMR106 cells. Our data are consistent with the interpretation that vanadium oxalate and citrate complexes hydrolyze to vanadate. Vanadium nitrilotriacetate would appear to be toxic for normal MC3T3E1 osteoblasts. In contrast, the vanadium tartrate complex induced a proliferative effect; however, it did not alter cell differentiation. 1997 Academic Press

Key Words: vanadate; aqueous vanadium chemistry; stability; spectroscopy; proliferation; differentiation; glucose consumption; protein content; alkaline phosphatase; osteoblast-like cells.

Vanadate mimics various insulin actions on different cell types and also in cell-free systems (1). These effects

\footnotetext{
${ }^{1}$ The first two authors were principal investigators.

${ }^{2}$ To whom correspondence should be addressed. Fax: 54-21-259485 or 53-0189. E-mail: cortizo@nahuel.biol.unlp.edu.ar.
}

include metabolic events such as stimulation of glucose transport, glucose metabolism, lipid synthesis, and stimulation of glucogen synthase as well as mitogenic activities like cell replication and DNA and protein synthesis $(2-7)$. In bone cells in particular, insulin has important physiological actions. It stimulates cell proliferation and increases DNA and collagen synthesis (8-10). In osteoblastic lines, insulin also has metabolic effects: it regulates alkaline phosphatase activity and stimulates the $\mathrm{Na}^{+} / \mathrm{K}^{+}$pump and glucose transport $(11-16)$. Likewise, vanadate has been shown to mimic several of the effects of insulin on osteoblast-like cells $(4-6,17)$.

Vanadium is an essential nutritional trace element in animals, but its function is not known. Vanadium deprivation induces skeletal deformation in the forelegs of goats (18). On the other hand, vanadium has been shown to induce toxic effects in several tissues at pharmacological doses. The most severe alterations were observed in rat kidney in a dose-dependent and cumulative manner $(19,20)$. Subcutaneous and oral administration of radioactive vanadium show that the soft tissues and blood contain the maximal concentration $2 \mathrm{~h}$ postadministration, whereas in bone the maximal level was found 1 day posttreatment (21).

We have recently shown a direct effect of vanadium derivatives on osteoblast-like UMR106 cells (17). Vanadate increased the cell growth in a biphasic manner, with an apparent cytotoxic effect at high doses. Alkaline phosphatase activity, a marker of osteoblast differentiation, was inhibited at the mitogenic doses of vanadate. On the other hand, $\mathrm{VOSO}_{4}$ and pervanadate were also mitogenic for these cells, whereas they did not affect cell differentiation.

The complex aqueous chemistry of vanadium compounds under conditions of physiological $\mathrm{pH}$ has been reported in studies $(22,23)$ in which the vanadium compounds being examined did not remain intact during 
the biological study (reviewed in 24). In the current work the biological response of different vanadium compounds, with varying stabilities under the physiological study conditions, has been examined. Although limited information is available on the nature of the vanadium compounds entering the cells $(25-28)$, these studies begin to provide information on the effects of modification of the vanadium atom by organic ligands $(29-33)$. Such information is essential in order to identify whether the suggested mechanism of action of vanadate or $\mathrm{VOSO}_{4}$ can indeed be attributed to an effect on protein-tyrosine-phosphatases or protein-tyrosine kinases (34-36).

The present study concerns the insulin-mimetic effects of vanadium derivatives on osteoblast-like cells in culture. Specifically, we demonstrate that such an effect is not limited to one type of osteoblast-like cells (UMR106) but is also observed with a second type of osteoblast-like cells (MC3T3E1). Furthermore, we determine the effects of a series of vanadium compounds, thus providing an insight on possible mechanisms of action in cultured cells, in the context of their complex aqueous chemistry. Thus, the aim of this study was to investigate the species of vanadium involved in specific insulin-like effects on osteoblast-like cells in culture.

\section{EXPERIMENTAL PROCEDURES}

Materials. Vanadate, p-nitrophenylphosphate, and ethylenediaminetetraacetic acid (EDTA) were obtained from Sigma. Tissue culture material was provided by Corning or Falcon, Dulbecco's modified Eagle's medium (DMEM) ${ }^{3}$ and trypsin were supplied by Gibco, and fetal bovine serum (FBS) was supplied by Gen, Argentina.

Spectroscopy. A combination of ${ }^{51} \mathrm{~V}$ NMR, uv-vis, and EPR spectroscopy was used to monitor each of the vanadium compounds in the cell media and in stock solutions. Specifically, ${ }^{51} \mathrm{~V}$ NMR spectroscopy at $79 \mathrm{MHz}$ was used to measure the stability of vanadium(V) compounds in solution. If the vanadium $(\mathrm{V})$ compound underwent redox chemistry, these measurements were confirmed by uv-vis spectroscopy (on a Perkin-Elmer lambda 4B), which gives different absorption spectra for various vanadium compounds. For example, uv-vis spectra of pure intact V-NTA and Vtar were used to obtain the extinction coefficients and/or absorbances of the original vanadium compounds. These coefficients were then used to monitor the disappearance and/or appearance of absorbances at various wavelengths. Since the DMEM medium is colored and absorbs in the uv and visible range, samples were examined in the presence and the absence of vanadium compounds, and the absorbance of the medium was substracted from the observed spectrum of the vanadium compounds. When vanadium(IV) compounds were added to the cell media (or formed during the experiment), EPR spectroscopy was also used to monitor these compounds.

Sample concentrations as analyzed by ${ }^{51} \mathrm{~V}$ NMR spectroscopy were $0.33-5.00 \mathrm{mM}$, by EPR spectroscopy $0.500-2.00 \mathrm{mM}$, and by uvvisible spectroscopy 2.50-15.0 mM. Additional experimental details

\footnotetext{
${ }^{3}$ Abbreviations used: Vi, vanadate; Voxal, vanadium oxalate; Vcitr, vanadium citrate; Vtar, vanadium tartrate; V-NTA, vanadium nitrilotriacetate; FBS, fetal bovine serum; DMEM, Dulbecco's modified Eagle's medium; ALP, alkaline phosphatase activity; PDGF, platelet derived-growth factor; PBS, phosphate-buffered saline.
}

for use of these methods have been described elsewhere (see, for example, Refs. 37-39).

Vanadium compounds and solution preparation. All chemicals obtained from Aldrich were reagent grade and used without further purification. The vanadium compounds were prepared as crystalline solids as described previously: $\mathrm{Na}_{4}\left[(\mathrm{VO})_{2}\left(\mathrm{C}_{4} \mathrm{H}_{2} \mathrm{O}_{6}\right)\right] \cdot 11 \mathrm{H}_{2} \mathrm{O}$ (40), $\mathrm{K}_{2}\left[\mathrm{VO}\left(\mathrm{O}_{2}\right)\left(\mathrm{C}_{6} \mathrm{H}_{6} \mathrm{NO}_{6}\right)\right] \cdot 2 \mathrm{H}_{2} \mathrm{O}(41), \mathrm{K}\left[\mathrm{VO}_{2}\left(\mathrm{C}_{6} \mathrm{H}_{6} \mathrm{O}_{7}\right)\right] \cdot \mathrm{H}_{2} \mathrm{O}$ (42), and $\left(\mathrm{NH}_{4}\right)_{3}\left[\mathrm{VO}_{2}\left(\mathrm{C}_{2} \mathrm{O}_{4}\right)_{2}\right] \cdot 2 \mathrm{H}_{2} \mathrm{O}$ (43). Stock solutions $(50.0 \mathrm{mM})$ of Vcitr, Voxal, V-NTA, and vanadate were prepared by dissolving the crystalline material in distilled water and stored at $0^{\circ} \mathrm{C}$. The solutions were found to be stable for days at various concentrations (ranging from submillimolar to $50 \mathrm{~mm}$ ). However, when these compounds were added to the DMEM media in the absence of cells (cell-free system) and the temperature was increased to $37^{\circ} \mathrm{C}$, their stability varied as described under Results.

Cell culture. Rat osteosarcoma cell line UMR106 was grown in DMEM supplemented with 10\% FBS and antibiotics (100 U/ml penicillin-100 $\mu \mathrm{g} / \mathrm{ml}$ streptomycin) in a humidified atmosphere of $95 \%$ air/5\% $\mathrm{CO}_{2}$. Cells were grown to near confluence $(70-80 \%)$ when they were subcultured using $0.1 \%$ trypsin- 1 mM EDTA in $\mathrm{Ca}^{2+}$ - and $\mathrm{Mg}^{2+}$-free phosphate-buffered saline (PBS). For experiments, about $2.5 \times 10^{4}$ cells/well were plated into 24 -well plates. MC3T3E1 cells were grown in DMEM-10\% FBS-antibiotics-5\% $\mathrm{CO}_{2}$. Cells were subcultured using trypsin-EDTA, plated into 24-well plates, and grown in DMEM-10\% FBS as previously described (44). In experiments where the MC3T3E1 cell line became confluent or cultured for a longer period (data not shown), these cells did not respond to PDGF, vanadate, or to any other vanadium compounds. Thus, it was essential to plate the cells at low density and to culture them for less than 3 days at subconfluence in order to observe the responses of PDGF and vanadate reported previously by Davidai et al. (7). After the culture reached $70 \%$ confluence, the cells were washed with DMEM without serum and incubated in $0.5 \mathrm{ml}$ DMEM plus different vanadium compounds for $24 \mathrm{~h}$. We chose these two cell lines since it was previously reported that they do respond to insulin and vanadium compounds $(7-17)$.

Cell proliferation assay. A mitogenic bioassay was carried out as described by Okajima et al. (45) with some modifications. Briefly, cells in 24-well plates were washed with PBS and fixed with 5\% glutaraldehyde/PBS at room temperature for $10 \mathrm{~min}$. Then they were stained with $0.5 \%$ crystal violet $/ 25 \%$ methanol for $10 \mathrm{~min}$. After that, the dye solution was discarded and the plate was washed with water and dried. The dye taken up by the cells was extracted using $0.5 \mathrm{ml} /$ well $0.1 \mathrm{M}$ glycine/HCl buffer, $\mathrm{pH} 3.0 / 30 \%$ methanol and transferred to test tubes. Absorbance was read at $540 \mathrm{~nm}$ after a convenient sample dilution. We have previously shown that under these conditions, the colorimetric bioassay strongly correlates with cell proliferation (17)

Alkaline phosphatase activity. Cells were incubated at $37^{\circ} \mathrm{C} / 24 \mathrm{~h}$ in a serum-free medium containing different agents. The cell layer was then washed with PBS and solubilized in $0.5 \mathrm{ml}$ of $0.1 \%$ Triton $\mathrm{X}-100$. Aliquots of the total cell extract $(10 \%)$ were used for protein determination using the Bradford technique (46) and for measurement of alkaline phosphatase activity $(10-20 \%)$ as has been previously described (17). This assay has been used as a marker of osteoblast-phenotype expression in cell cultures $(44,47,48)$.

Glucose consumption assay. Cells in 24-well plates were cultured with different vanadium compounds in $0.5 \mathrm{ml}$ serum-free DMEM. After $24 \mathrm{~h}$ at $37^{\circ} \mathrm{C}$, the conditioned medium was removed and separated from of cells by centrifugation at $8000 \mathrm{~g} / 3 \mathrm{~min}$. The glucose concentration remaining in the medium was measured by the glucose oxidase enzymatic method (Wiener Lab., Argentina), as described previously (45).

Morphology. Cells were plated into 35-mm dishes at a density of $2 \times 10^{4}$ cells/dish. After $24 \mathrm{~h}$, they were washed with DMEM and incubated in fresh DMEM plus different vanadium compounds (25 
$\mu \mathrm{M})$ for an additional $24 \mathrm{~h}$. Cells were subsequently washed and stained with crystal violet as before, and morphological changes were examined microscopically.

Statistical methods. At least three experiments were performed by triplicate for each experimental condition. Data are expressed as the mean \pm SEM. Statistical differences were analysed using Student's $t$ test or analysis of variance when suitable. Linear correlation analysis was performed by Pearson's correlation coefficient.

\section{RESULTS}

Stability studies in the cell media. The vanadium chemistry under physiological conditions is complex and poorly understood even for well-known vanadium compounds and compounds often used in biological studies $(22,24,29)$. Attributing a certain biological response to a particular vanadium compound is therefore difficult and has not been appropriately considered in studies with vanadium compounds (24). Although it is not known which compounds are transported into the cells, information on the stability of each compound during cell treatment and determination of what other compounds form during the cell incubation will provide a valuable basis to interpret the mechanism of the observed effects. Figure 1 shows the ${ }^{51} \mathrm{~V}$ NMR spectra of a solution of $2.5 \mathrm{mM}$ V-NTA in DMEM media immediately after dissolution of the compound. An identical spectrum is observed for a concentration of stock solution of V-NTA (spectrum not shown). The spectra at 5 and 22 h clearly show hydrolysis of a significant fraction of the V-NTA complex, and signals attributed to vanadate are observed in the ${ }^{51} \mathrm{~V}$ NMR spectra (the speciation of vanadate at neutral $\mathrm{pH}$ has been previously reviewed in Ref. 29). Voxal and Vcitr also form vanadate in the cell media, although hydrolysis of these compounds is significantly faster than that illustrated for V-NTA in Fig. 1 (for some experimental data see Fig. 2, left). The vanadium(IV) compound Vtar showed $50 \%$ hydrolysis after $22 \mathrm{~h}$ of incubation in the cell media. The hydrolyzed vanadium(IV) species then oxidized to vanadate (as monitored by both ${ }^{51} \mathrm{~V}$ NMR and EPR spectroscopies; data not shown).

The cells were incubated with vanadium compounds at concentration of $25 \mu \mathrm{M}$. The analytical methods available do not allow for distinction among different vanadium species in solution at this concentration. It was necessary to measure their stability at higher concentrations and to estimate the existence of each vanadium compound in the DMEM media under cell growth conditions. Thus, the stability studies of vanadium compounds were carried out in a cell-free system, in DMEM media at $37^{\circ} \mathrm{C}$, pH 7.4. Since the relative stability of the V-NTA and Vtar complexes are dependent on the concentration of the compound, a series of at least six different concentrations were followed up to $24 \mathrm{~h}$. For example, a $5.0 \mathrm{~mm}$ V-NTA solution contained $>65 \%$ compound after $24 \mathrm{~h}$, whereas a $0.50 \mathrm{~mm}$ V-NTA

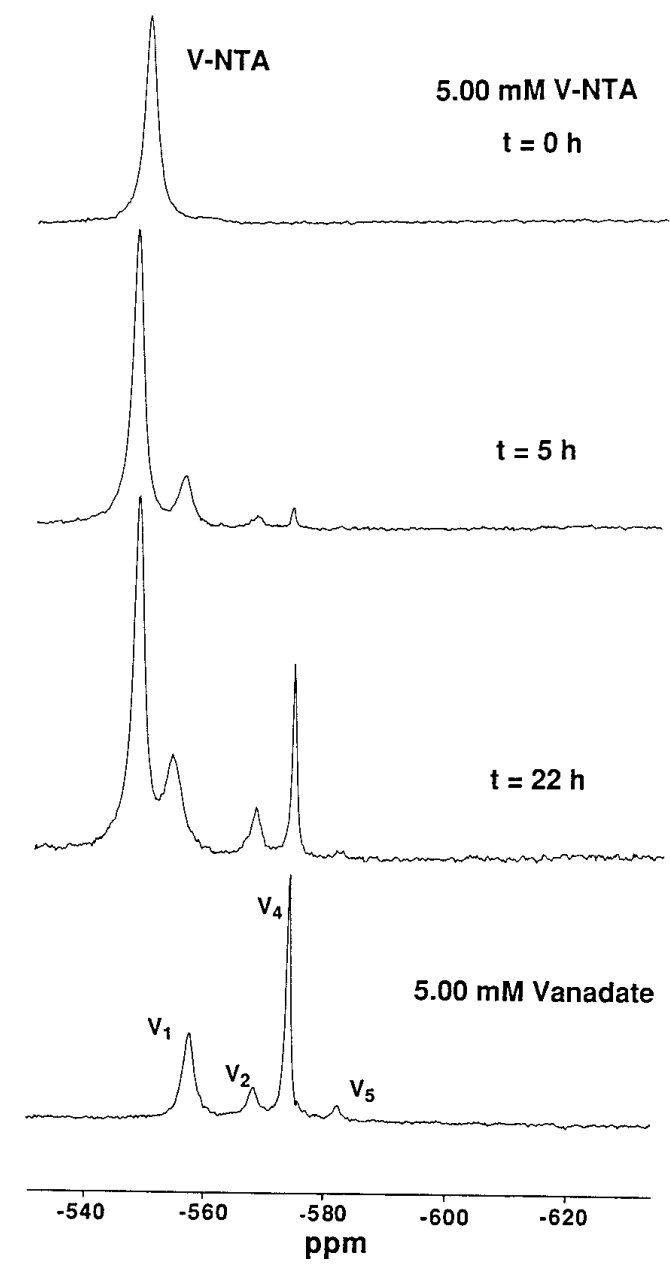

FIG. 1. The ${ }^{51} \mathrm{~V}$ NMR spectra of $5.0 \mathrm{~mm}$ V-NTA are shown immediately after dissolution of the compound in the cell medium (top), after $5 \mathrm{~h}$, and at $22 \mathrm{~h}$. The ${ }^{51} \mathrm{~V}$ NMR spectrum of a solution of DMEM media at $37^{\circ} \mathrm{C}$ containing $5.0 \mathrm{~mm}$ vanadate is shown for comparison. Signals due to V-NTA and vanadate oligomers $\left(\mathrm{V}_{1}, \mathrm{~V}_{2}, \mathrm{~V}_{4}\right.$, and $\left.\mathrm{V}_{5}\right)$ are indicated.

solution contained about $20 \%$ compound after $24 \mathrm{~h}$ (data shown in Fig. 2 are for 5.0 mm compounds). These studies allowed us to estimate the speciation of vanadium compounds at $25 \mu \mathrm{M}$ even though the detailed decomposition reactions of these compounds in the presence of cell media are not fully understood (decomposition is likely to involve both hydrolysis and redox reactions). The projected stability curves for $25 \mu \mathrm{M}$ of each vanadium compound are shown in Fig. 2 (right). From this figure it can be seen that Voxal is hydrolyzed immediately and Vcitr is essentially $100 \%$ converted to vanadate after $7 \mathrm{~h}$. However, some of the V-NTA and the Vtar compounds remain unchanged in solution, although both of these species also form significant concentrations of vanadate. For example, after $24 \mathrm{~h}$ incubation with $25 \mu \mathrm{M}$ Vtar, 10 to $15 \mu \mathrm{M}$ vanadate was formed. 

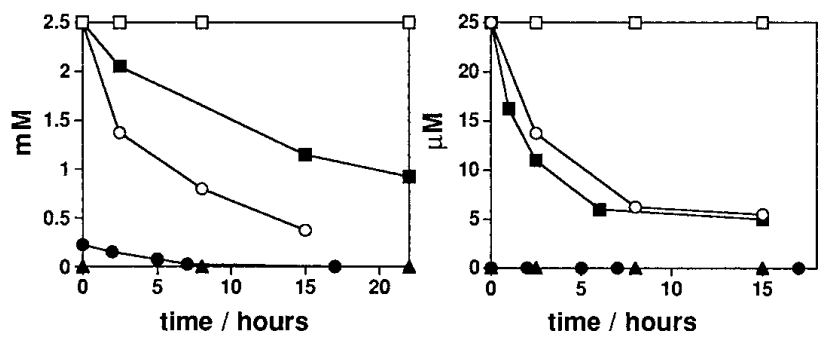

FIG. 2. Experimental data at $2.5 \mathrm{~mm}$ (left) and estimated stabilities at $25 \mu \mathrm{M}$ (right) of vanadium compounds in DMEM media at $37^{\circ} \mathrm{C}$. The information is based on experimental determination of the stability of each vanadium compound using a combination of ${ }^{51} \mathrm{~V}$ NMR, $\mathrm{EPR}$, and uv-vis spectroscopy of the respective compounds in concentrations ranging from 0.33 to $15.0 \mathrm{~mm}$. A minimum of five different concentrations for each vanadium compound were followed for up to $24 \mathrm{~h}$ under the conditions of cell growth. The symbols represent vanadate $(\square)$, V-NTA $(\square)$, Vtar $(\bigcirc)$, $\operatorname{Vcitr}(\bullet)$, and Voxal $(\boldsymbol{\Delta})$.

Since all four compounds generate vanadate upon incubation with the cell media we would expect that all four vanadium compounds would exhibit some of the biological responses of vanadate, albeit at different levels. Both V-NTA and Vtar remain intact for longer periods of time and thus have the potential to exhibit a response which could be differentiated from that of vanadate.

Effect of vanadium compounds on cell growth. Figure 3 shows the proliferation assay, as measured by the crystal violet bioassay, after $24 \mathrm{~h}$ of exposure of osteoblast-like cells to $25 \mu \mathrm{M}$ of a series of vanadium
TABLE I

Effect of Different Vanadium Compounds on Cell Protein Content

\begin{tabular}{lcc}
\hline & \multicolumn{2}{c}{ Protein $[\mu \mathrm{g} /$ well $]$} \\
\cline { 2 - 3 } Compounds & UMR 106 cells $(n=7)$ & MC3T3E1 cells $(n=8)$ \\
\hline None (basal) & $118 \pm 1$ & $40 \pm 3$ \\
Vanadate & $169 \pm 3^{* *}$ & $48 \pm 2^{*}$ \\
Voxal & $173 \pm 5^{* *}$ & $47 \pm 2^{*}$ \\
Vcitr & $173 \pm 4^{* *}$ & $52 \pm 2^{* *}$ \\
Vtar & $159 \pm 2^{* *}$ & $52 \pm 3^{* *}$ \\
V-NTA & $163 \pm 2^{* *}$ & $42 \pm 6$ \\
\hline
\end{tabular}

Note. Cells were incubated with $25 \mu \mathrm{M}$ vanadium compounds at $37^{\circ} \mathrm{C} / 24 \mathrm{~h}$. Protein content was evaluated as described under Experimental Procedures. Results are expressed as $X \pm$ SEM; differences versus basal are ${ }^{*} P<0.01$ and ${ }^{* *} P<0.001$.

compounds. Vanadate, Voxal, Vcitr, and V-NTA strongly stimulated cell proliferation in UMR106 cells (Fig. 3A). On a molar basis, Vtar was less effective than vanadate (115 \pm 3 vs $133 \pm 8$, respectively; $P<0.05)$, but still induced cell growth. On the other hand, in MC3T3E1 cells (Fig. 3B), vanadate, Voxal, Vcitr, and Vtar increased cell proliferation to the same extent, while V-NTA did not affect the proliferation of this cell line as tested in three independent experiments.

The effect of vanadium derivatives on total cell protein was also assessed (Table I). At $25 \mu \mathrm{M}$, all vanadium derivatives significantly increased total protein content
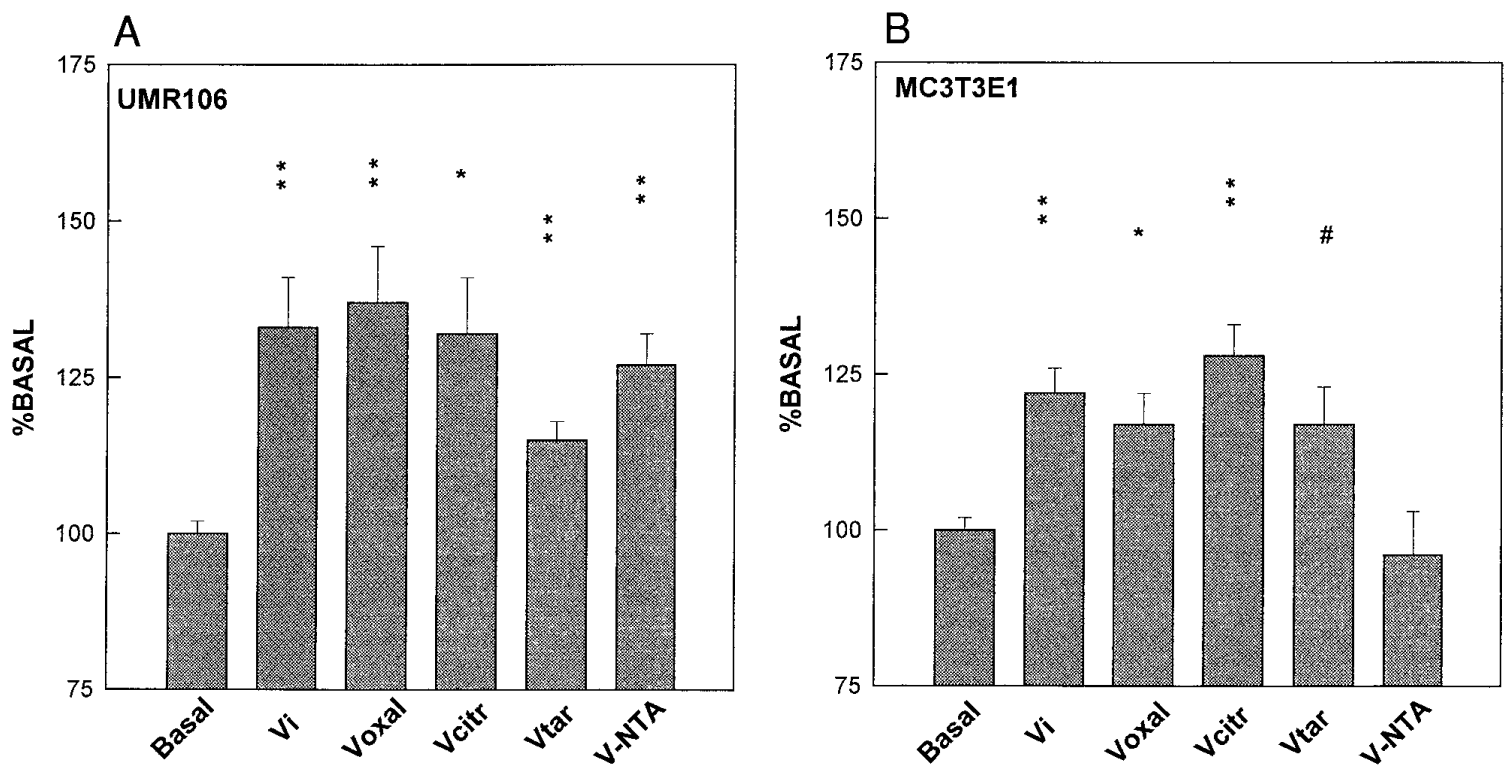

FIG. 3. Effect of different vanadium compounds on cell proliferation. UMR106 (A) and MC3T3E1 (B) were incubated with $25 \mu \mathrm{M}$ of Vi (vanadate), Voxal, Vcitr, Vtar, or V-NTA, at $37^{\circ} \mathrm{C} / 24 \mathrm{~h}$. Results are expressed as \% basal, $X \pm \mathrm{SEM}, n=8$, MC3T3E1 and $n=11$, UMR106. Basal values are $9.5 \times 10^{4}$ cell/ml (UMR106) and $2.2 \times 10^{4}$ cell/ml (MC3T3E1). Differences vs basal are $\# P<0.02,{ }^{*} P<0.01$, and ${ }^{* *} P<$ 0.001 . 
TABLE II

Effect of Vanadium Compounds on Glucose Consumption

Glucose consumed [mg/dl]

Compounds UMR 106 cells $(n=9) \quad$ MC3T3E1 cells $(n=12)$

\begin{tabular}{lcl}
\hline None (basal) & $87 \pm 7$ & $39 \pm 4$ \\
Vanadate & $185 \pm 7^{* *}$ & $63 \pm 6^{*}$ \\
Voxal & $176 \pm 8^{* *}$ & $55 \pm 3^{*}$ \\
Vcitr & $186 \pm 9^{* *}$ & $60 \pm 3^{* *}$ \\
Vtar & $179 \pm 13^{*}$ & $56 \pm 4^{*}$ \\
V-NTA & $218 \pm 12^{* *}, \#$ & $55 \pm 4^{*}$
\end{tabular}

Note. Cells were incubated with $25 \mu \mathrm{M}$ vanadium compounds at $37^{\circ} \mathrm{C} / 24$ h. Glucose consumption was evaluated as described under Experimental Procedures. Results are expressed as $X \pm \mathrm{SEM}$; differences versus basal are ${ }^{*} P<0.01,{ }^{* *} P<0.001$; difference vs vanadate, $\# P<0.05$.

in UMR106 osteoblast-like cells. The effect of vanadium compounds on cell protein was also tested on the MC3T3E1 line. Vanadate, Voxal, Vcitr, and Vtar significantly enhanced protein content with a pattern similar to that of the crystal violet experiments. Thus, it is possible that the changes in protein content may be a reflection of the changes in cell proliferation. V-NTA did not alter the cellular protein levels in MC3T3E1 cells, although a considerable variability between different assays was observed. This finding was in agreement with the lack of stimulation of V-NTA on MC3T3E1 cell proliferation.

Effect of vanadium compounds on glucose consumption. All tested vanadium derivatives significantly increased glucose consumption in both MC3T3E1 and UMR106 osteoblast-like cells over basal values after a 24-h incubation (Table II). The effects were similar for all vanadium derivatives tested at $25 \mu \mathrm{M}$ concentration, with the exception of V-NTA, which was more potent than vanadate on the UMR106 line.

Vanadium derivatives inhibit cell differentiation. The osteoblast-like phenotype was assessed by the specific activity of alkaline phosphatase. In UMR106 cells, vanadate, Voxal, Vcitr, and V-NTA statistically inhibited cell differentiation, whereas the vanadium(IV) derivative Vtar showed no effect (Fig.4).

In these experiments the MC3T3E1 cells were cultured for relatively short periods (3 days) and the ALP activity was very low, since these cells had not yet reached their typical osteoblast phenotype (44). Thus, this parameter could not be evaluated in this cell line.

Morphology. During the course of the incubation with vanadium compounds, it was observed that in contrast to the osteosarcoma UMR106 cells, the MC3T3E1 osteoblasts suffered morphological changes. In the MC3T3E1 cells exposed to $25 \mu \mathrm{M}$ vanadium compounds, the extent of the morphological changes was evident after $12 \mathrm{~h}$ of incubation. Control cultures showed polyhedral cells with slender lamellar expansions (Fig. 5A). These expansions appeared to join to each other among neighboring cells. The nuclei showed moderately thick chromatin granules. The perinuclear cytoplasm had numerous organelles and vacuoles, while the exoplasm was diffuse and homogeneous. Cells incubated with vanadate, Voxal, and Vcitr became spindle-like and condensed. When Vtar was tested on MC3T3E1 cells, slight morphological transformations were observed after $24 \mathrm{~h}$ incubation. A detailed microscopic observation of the cell preparation showed a heterogeneous cellular population, with a main proportion of normal cells and small number of condensed and retractile cells (data not shown). V-NTA was the strongest morphological transformer in MC3T3E1 cells. In cultures treated with this peroxocompound, cells were long and fusiform in shape, with very dense cytoplasm and well-defined borders, and without connections between cells (Fig. 5B).

\section{DISCUSSION}

Insulin, like other growth factors, regulates cell proliferation, differentiation, and acute metabolic processes in a variety of cells $(4-7,17)$. Vanadate induces insulin-like effects in animals and also in cultures of bone-related cells $(4-6,17)$. The insulinlike effect has been demonstrated in primary cultures such as rat calvaria cells or rabbit condrocytes as well as in cloned cell lines by enhanced synthesis of

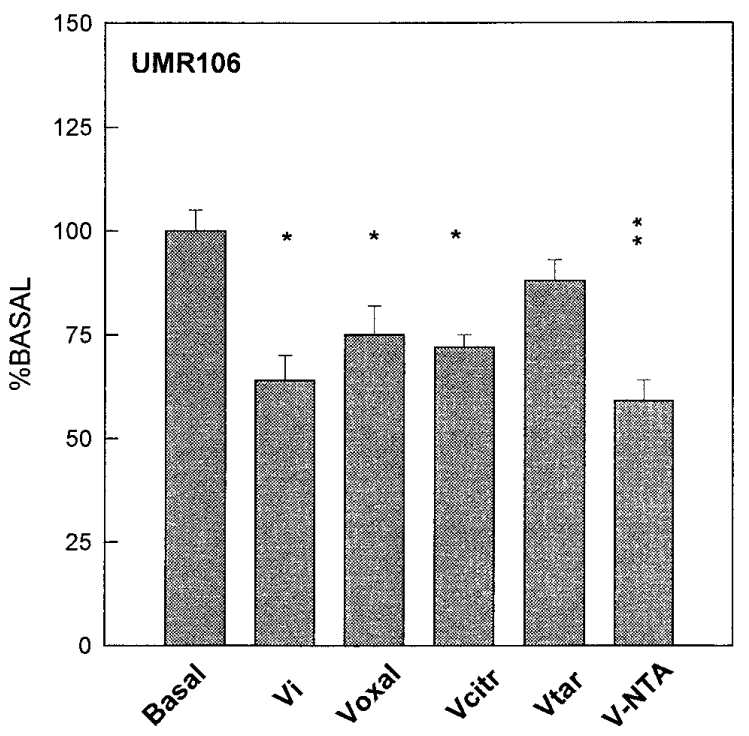

FIG. 4. Effect of vanadium compounds on UMR106 alkaline phosphatase specific activity. Cells were incubated with $25 \mu \mathrm{M}$ of Vi (vanadate), Voxal, Vcitr, Vtar, or V-NTA, at $37^{\circ} \mathrm{C} / 24 \mathrm{~h}$. Results are expressed as \% basal, $X \pm \mathrm{SEM}, n=9$. Basal value is $340 \pm 38 \mathrm{nmol} /$ $\mathrm{min} / \mathrm{mg}$ protein. Differences vs basal are ${ }^{*} P<0.01$, and ${ }^{* *} P<0.002$. 



FIG. 5. MC3T3E1 incubated in DMEM (control) (A). Effect of V-NTA $25 \mu \mathrm{M}$ for $24 \mathrm{~h}$ (B). After this period, cells were stained with crystal violet. $\mathrm{Obj}, \times 40$.

DNA and of collagen and other extracellular matrix proteins. In addition to vanadate, we have recently reported that $\mathrm{VOSO}_{4}$ and pervanadate also stimulated cell proliferation in UMR106 osteosarcoma cells (17). Cell lines (osteosarcoma vs normal osteoblasts) synthesize and secrete different amounts of growth factors (49) and are likely to respond differently to exogenous agents. In the present report we focus our attention on demonstrating that the effects of vanadate and other vanadium compounds are not limited to the UMR106 osteosarcoma cells but are also exhib- ited by another osteoblast-like cell line, the MC3T3E1 cells. The latter is a murine calvaria-derived osteoblast-like cell line and shares many features with osteoblasts (50). It is responsive to insulin as well as to other growth factors (PDGF, IGF-I, estrogen) (49) and has been previously used as a model to study osteoblast differentiation and mineralization (47).

The effect of high cell density on the responsiveness to exogenously added compounds is not limited to the MC3T3E1 cells but has also been previously reported 
for other cell types (51). It is possible that under highdensity conditions, considerable amounts of growth factors (like IGF-I) may down-regulate their specific receptors, rendering the cells unresponsive to exogenous mitogens. However, using conditions similar to ours, Davidai et al. (7) found that vanadate increased thymidine incorporation into DNA and synergized the PDGF growth-promoting effect. Our results are in agreement with their findings and furthermore demonstrate an effect by other vanadium compounds. The response of cell line UMR106 to vanadate was similar to that of MC3T3E1: vanadate increased cell proliferation (as measured by crystal violet assay), protein content, and glucose consumption (Fig 3; Tables I and II).

Vanadate, Voxal, and Vcitr increased cell proliferation, protein content, and glucose consumption to the same extent in UMR106 and MC3T3E1 cells (Fig.3; Tables I and II). These three compounds also inhibited the ALP-specific activity in the former cell line (Fig. 4). These results were also reproduced in a series of experiments performed in the presence of $25 \mu \mathrm{M}$ EDTA and thus suggest that the effect of vanadium compounds on cell differentiation, as assessed by ALP activity, is not a direct in vitro inhibitory effect of vanadium compounds but probably a change in the enzyme content as we have previously suggested (17).

The observed biological responses of Voxal and Vcitr are consistent with the hydrolysis of each vanadium derivative to vanadate and free ligand. Indeed, Voxal is rapidly hydrolyzed in the culture media as shown by ${ }^{51} \mathrm{~V}$ NMR (Fig. 2) and suggested by previous studies with these compounds (24). Even though Vcitr is significantly more stable, it partially hydrolyzed under our incubation conditions (Fig. 2), and the effects of this compound cannot be distinguished from the effect of vanadate (Figs. 3 and 4; Tables I and II).

Vtar is a relatively stable vanadium(IV) compound in DMEM medium. After $15 \mathrm{~h}$ of incubation at $37^{\circ} \mathrm{C}$, about 10 to $20 \mu \mathrm{M}$ vanadate was generated from $25 \mu \mathrm{M}$ Vtar. Under our experimental conditions, Vtar did not affect UMR106 differentiation (Fig. 4) but stimulated cell proliferation, protein content, and glucose consumption (Fig. 3; Tables I and II) in either UMR106 or MC3T3E1 osteoblasts. The lack of effect of this compound on ALP-specific activity of UMR106 cells (Fig. 4), a marker of osteoblast differentiation, is consistent with our previous results with $\mathrm{VOSO}_{4}$ (17). On the other hand, this vanadium(IV) compound slightly affected cell morphology, in contrast to the tested vanadi$\mathrm{um}(\mathrm{V})$ derivatives. It was observed early that vanadate causes morphological changes in different cell systems such as kidney and fibroblast cells $(52-55)$, ovarian granulosa cells (56), hamster embryo cells (57), and the bovine papilloma virus DNA-transfected C3H10T1/2 line (58). Altogether, our results suggest that Vtar behaves partially like vanadate (increasing cell growth and glucose consumption) and partially like $\mathrm{VOSO}_{4}$ (without affecting ALP activity and cell morphology). These observations are consistent with the partial hydrolysis observed for these compounds in the cell medium (Fig. 2).

V-NTA, the only peroxo-compound examined in this work, is particularly interesting because of its stability and observed biological effects. About $20 \%$ of the complex remains after $15 \mathrm{~h}$ incubation in DMEM medium. The fact that the cellular response to V-NTA deviates from that of vanadate suggests that V-NTA acts in a significantly different way than vanadate (albeit considering that some V-NTA does generate vanadate upon incubation with the cell media). This compound affected UMR106 cell proliferation and differentiation to a magnitude indistinguishable from that of vanadate (Figs. 3A and 4; Table I). However, it was statistically significantly more potent than vanadate in increasing glucose consumption in UMR106 cells $(P<0.05)$ (Table II). On the other hand, V-NTA did not affect mitogenesis (Fig. 3B) or cell protein content (Table I) in MC3T3E1 cells under our working conditions. These observations would be consistent with the possibility of V-NTA not being taken up and/or metabolized by the MC3T3E1 osteoblast-like cells but inconsistent with the observed enhanced glucose consumption (Table II). This could suggest that this compound exerts selective effects on MC3T3E1 cells. Furthermore, the morphological studies showed that V-NTA was the strongest morphological transformer in MC3T3E1 cells (Fig. 5). Transformation suggests that this compound may have cytotoxic effects on the normal osteoblast MC3T3E1 cell lines, as has been previously suggested for other peroxovanadium derivatives (59). The experimental evidence presented here is consistent with the possibility that tumorigenic and normal osteoblast-like cells could respond differently to some vanadium compounds, as in the case of V-NTA.

In conclusion, Voxal and Vcitr induce insulin-like effects on osteoblast-like cells similar to those of vanadate. These effects are consistent with their rapid hydrolysis to vanadate. In contrast, relatively stable compounds such as Vtar and V-NTA exhibit certain responses, some of which are not observed with vanadate. These studies clearly demonstrate that modified vanadium compounds given sufficient stability will show some selectivity in their biological action.

\section{ACKNOWLEDGMENTS}

We thank Miss Nyria Fenoglio for language revision. S.B.E. is member of the Carrera del Investigador, CONICET, Argentina, and A.M.C. is member of the Carrera del Investigador, CICPBA, Argentina. This work was partially supported by grants from Facultad de Ciencias Exactas (UNLP) and Universidad Nacional de La Plata (UNLP), Argentina. D.C.C. thanks NIH and Sloan Foundation for support. 


\section{REFERENCES}

1. Shechter, Y. (1990) Diabetes 39, 1-5.

2. Hori, C., and Oka, T. (1990) Biochim. Biophys. Acta 610, 235240.

3. Smith, J. B. (1983) Proc. Natl. Acad. Sci. USA 80, 6162-6166.

4. Canalis, E. (1985) Endocrinology 116, 855-862.

5. Lau, K. H. W., Tanimoto, H., and Baylink, D. J. (1988) Endocrinology 123, 2858-2867.

6. Kato, Y., Iwamoto, M., Koike, T., and Suzuki, F. (1987) J. Cell Biol. 104, 311-319.

7. Davidai, G., Lee, A., Schvartz, Y., and Hazum, E. (1992) Am. J. Physiol. 263, E205-E209.

8. Kream, B. E., Smith, M. D., Canalis, E., and Raisz, L. G. (1985) Endocrinology 116, 296-302.

9. Hickman, J., and McElduff, A. (1989) Endocrinology 124, $701-$ 706.

10. Felsenfeld, A. J., Iida-Klein, A., and Hahn, T. J. (1992) J. Bone Miner. Res. 7, 1319-1325.

11. Levy, J. R., Murray, E., Manolagas, S., and Olefsky, J. M. (1986) Endocrinology 119, 1786-1792.

12. DeLuise, M. A., and Harker, M. (1988) Diabetes 37, 33-37.

13. Ituarte, E. A., Halstead, L. R., Iiida-Klein, A., Ituarte, H. G., and Hahn, T. J. (1989) Calcif. Tissue Int. 45, 27-33.

14. Ituarte, E. A., Ituarte, H. G., Iida-Klein, A., and Hahn, T. J. (1989) J. Bone Miner. Res. 4, 69-73.

15. Thomas, D. M., Rogers, S. D., Sleeman, M. W., Pasquini, G. M., Bringhurst, F. R., Ng, K. W., Zajac, J. D., and Best, J. D. (1995) J. Mol. Endocrinol. 14, 263-275.

16. Pun, K. K., Lau, P., and Ho, P. W. M. (1989) J. Bone Miner. Res. 4, 853-862.

17. Cortizo, A. M., and Etcheverry, S. B. (1995) Mol. Cell Biochem. 145, $97-102$.

18. Nielsen, F. H. (1991) FASEB J. 5, 2661-2667.

19. Al-Bayati, M. A., Giri, S. N., Raabe, O. G., Rosenblatt, L. S., and Shifrine, M. (1989) J. Environ. Pathol. Toxicol. Oncol. 9, 435455.

20. Higashino, H., Bogden, J. D., Lavenhar, M. A., Bauman, J. W., Jr., and Hirotsu, T. (1983) Am. J. Physiol. 244, F105-F111.

21. Al-Bayati, M. A., Raabe, O. G., Giri, S. N., and Knaak, J. B. (1991) J. Am. Coll. Toxicol. 10, 223-241.

22. Crans, D. C. (1994) Commun. Inorg. Chem. 16, 1-33.

23. Crans, D. C., Keramidas, A. D., and Drouza, C. (1996) Phosphorus, sulfur, and silicon. 109-110, 245-248.

24. Crans, D. C., Mahroof-Tahir, M., and Anastasios, K. D. (1995) Mol. Cell Biochem. 153, 17-24.

25. Degani, H., Gochin, M., Karlish, S. J. D., and Shechter, Y. (1981) Biochemistry 20, 5595-5597.

26. Heinz, A., Rubinson, K. A., and Grantham, J. J. (1982) J. Lab. Clin. Med. 100, 593-612.

27. Willsky, G. R., and Dosh, S. F. (1986) Yeast 2, 77-85.

28. Sabbioni, E., Pozzi, G., Devos, S., Pintar, A., Casella, L., and Fischbachm, M. (1993) Carcinogenesis 14, 2565-2568.

29. Crans, D. C. (1994) Commun. Inorg. Chem. 16, 35-76.

30. Kustin, K., and Toppen, D. L. (1973) J. Am. Chem. Soc. 95, $3564-$ 3568.
31. Macara, I. G., Kustin, K., and Cantley, L. C., Jr. (1980) Biochim. Biophys. Acta 629, 95-106.

32. Sakurai, H., Shimomura, S., and Ishizu, K. (1981) Inorg. Chim. Acta 55, L67-L69.

33. Chen, Y., and Chan, T. M. (1993) Arch. Biochem. Biophys. 305, $9-16$.

34. Nechay, B. R. (1984) Annu. Rev. Pharmacol. Toxicol. 24, 501524.

35. Lau, K. H. W., Farley, J. R., and Baylink, D. J. (1989) Biochem. J. 257, 23-36.

36. Gresser, M. J., and Tracey, A. S. (1990) in Vanadium in Biological Systems (Chasteen, N. D., Ed.), pp. 63-79, Kluwer, The Netherlands.

37. Crans, D. C., Holst, H., Keramidas, A. D., and Rehder, D. (1995) Inorg. Chem. 34, 2524-2534.

38. Crans, D. C., and Shin, P. K. (1994) J. Am. Chem. Soc. 116, $1305-1315$.

39. Chasteen, N. D. (1981) in Biological Magnetic Resonance (Reuben, J., Ed.), pp 53-119, Plenum, New York.

40. Tapscott, R. E., and Belford, R. L. (1967) Inorg. Chem. 6, 735 743.

41. Djordjevic, C., Wilkins, P. L., Sinn, E., and Butcher, R. L. (1995) Inorg. Chim. Acta 230, 241-244.

42. Djordjevic, C., Lee, M., and Sinn, E. (1989) Inorganic Chemistry 28, 719-723.

43. Sathyanarayana, D. N., and Patel, C. C. (1964) Bull. Chem. Soc. Jap. 37, 1736-1740.

44. Quarles, D. L., Yohay, D. A., Lever, L. W., Caton, R., and Wenstrup, R. (1992) J. Bone Miner. Res. 7, 683-692.

45. Okajima, T., Nakamura, K., Zhang, H., Ling, N., Tanabe, T., Yasuda, T., and Rosenfeld, R. G. (1992) Endocrinology 130, 2201-2212.

46. Bradford, M. (1976) Anal. Biochem. 72, 248-254.

47. Stein, G. S., and Lian, J. B. (1993) Endocrine Rev. 14, 424-442.

48. Schmid, C. H., Steiner, T. H., and Froesch, E. R. (1983) Calsif. Tissue Int. 35, 578-585.

49. Mohan, S., and Baylink, D. J. (1994) in Current Directions in Insulin-Like Growth Factor Research (LeRoith, D., and Raizada, M. K., Eds.), pp. 397-406, Plenum, New York.

50. Sudo, H., Kodama, H., Amagai, Y., Yamamoto, S., and Kasai, S. (1988) J. Cell Biol. 96, 191-198.

51. Hill, D. J., Camacho-Hübner, C., Rashid, P., Strain, A. J., and Clemmons, D. R. (1989) J. Endocrinol. 122, 87-98.

52. Karlung, J. K. (1985) Cell 41, 707-717.

53. Mountjoy, K. G., and Flier, J. S. (1990) Endocrinology 127, 2025-2034.

54. Cortizo, A. M., Salice, V. C., Vescina, C. M., and Etcheverry, S. B. (1996) Biometals, in press.

55. Sabbioni, E., Pozzi, G., Pintar, A., Casella, L., and Garrantini, S. (1991) Carcinogenesis 12, 47-52.

56. Aharoni, D. (1993) Endocrinology 133, 1426.

57. Rivedal, E., Roseng, L. E., and Sanner, T. (1990) Cell Biol. Toxicol. 6, 303-314.

58. Kowalski, L. A., Tsang, S.-S., and Davison, A. J. (1992) Cancer Lett. 64, 83-90.

59. Stankiewicz, P. J., Tracey, A. S., and Crans, D. C. (1995) in Metal Ions in Biological Systems (Sigel, H., and Sigel, A., Eds.), pp. 287-324, Dekker, New York. 